Research Article

\title{
Trace Element Status and Environmental Implications of Soils and Zea mays from Farmed Dumpsites in the Bamenda Metropolis, North-West Cameroon
}

\author{
Mofor Nelson Alakeh $\mathbb{D}^{1}{ }^{1}$ Njoyim Estella Buleng Tamungang, ${ }^{2,3}$ Mbene Kenneth, \\ Yuhinwenkeh Njumbo Blaise, ${ }^{2}$ and Nchofua Festus Biosengazeh ${ }^{3}$ \\ ${ }^{1}$ Department of Mining and Mineral Engineering, National Higher Polytechnic Institute (NAHPI), The University of Bamenda, \\ Bambili, Cameroon \\ ${ }^{2}$ Department of Chemistry, Higher Teacher Training College, The University of Bamenda, Bambili, Cameroon \\ ${ }^{3}$ Research Unit of Noxious Chemistry and Environmental Engineering (RUNOCHEE), Department of Chemistry, \\ Faculty of Science, University of Dschang, Dschang, Cameroon \\ ${ }^{4}$ Department of Chemistry, Higher Teacher Training College, University of Yaounde 1, P.O. Box 47, Yaounde, Cameroon
}

Correspondence should be addressed to Mofor Nelson Alakeh; nelsonmofor@yahoo.com

Received 11 August 2020; Revised 3 September 2020; Accepted 21 September 2020; Published 7 October 2020

Academic Editor: Fedor Lisetskii

Copyright ( $\odot 2020$ Mofor Nelson Alakeh et al. This is an open access article distributed under the Creative Commons Attribution License, which permits unrestricted use, distribution, and reproduction in any medium, provided the original work is properly cited.

\begin{abstract}
This study assessed some physicochemical and trace element properties of soils and Zea mays from farmed dumpsites in the Bamenda metropolis, North-West Cameroon. The growth in population and metal workshops in Bamenda has resulted in the dumping of large quantities of wastes on agricultural soils. Thus, the fear of these agricultural soils and crops being contaminated by waste dumped on them is a call for concern because most of the populations rely on agriculture for survival. A soil and Zea mays sample each was collected from three farmed dumpsites (Nkwen, Mankon, and Bamendakwe) in the Bamenda metropolis and analyzed for physicochemical and trace element properties using standard procedures. The results of physicochemical analysis revealed that the soils had $\mathrm{pH}$ values ranging from 5.63 to 7.49 , average organic matter, low total nitrogen, high $\mathrm{C} / \mathrm{N}$ ratio, and high CEC, and the soil textural class was clay loam for soils of Nkwen and sandy loam for soils of Mankon and Bamendakwe. The content of bases in Zea mays was high compared to those in the soil. The concentration of Fe $(14635.6 \mu \mathrm{g} / \mathrm{g})$ in soils of Bamendakwe and $\mathrm{Cu}(157.17 \mu \mathrm{g} / \mathrm{g})$ and $\mathrm{Zn}(1438.36 \mu \mathrm{g} / \mathrm{g})$ in soils of Mankon had values which were above the permissible limit. The concentration of $\mathrm{Zn}(114.48 \mu \mathrm{g} / \mathrm{g})$ in the plant sample of Mankon together with the concentration of Fe in all three plant samples had values above permissible limits. Natural origins and domestic waste were identified as the major sources of trace metals in the soils. Thus, there are potential health hazards related to consuming crops from such soils. Bioremediation techniques can be used to recover heavy metals from such soils. Furthermore, the mobilization of nutrient ions and immobilization of heavy metals by induced liming could be important in sustainable agricultural production and soil environmental protection of the soils studied.
\end{abstract}

\section{Introduction}

Environmental pollution is a worldwide problem, and its potential in influencing public health is great [1-3]. The impact of pollution near congested cities has reached a disturbing magnitude, coupled with soil pollution which is arousing public awareness [4]. Soils may become contaminated through the accumulation of trace elements and metalloids resulting from wastes dumped on them. Trace metal soil contamination may result from natural sources such as weathering of parent materials at levels that are regarded as trace and rarely toxic, but upon constant accumulation, it reaches toxic levels [2, 5-7]. Trace element contamination of soils could also result from anthropogenic sources such as rapidly expanding industrial areas, disposal of high metal wastes, leaded gasoline and 
paints, land application of fertilizers, sewage sludge, pesticides, wastewater irrigation, coal combustion residues, spillage of petrochemicals, and atmospheric deposition [8, 9]. Some trace elements $(\mathrm{Fe}, \mathrm{Cu}, \mathrm{Mn}$, and $\mathrm{Zn}$, amongst others) function as essential nutrients to plants and can directly influence the growth and energygenerating processes of plants due to their high reactivity within the soil system [10]. When the concentration of these trace elements in the soil goes above permissible limits, it becomes toxic to plants [11]. Trace element solubility in soil and bioavailability to plants is mainly influenced by the chemical properties of soil such as soil $\mathrm{pH}$, cation exchange capacity (CEC), soil texture, and organic matter (OM) [12].

With increasing population growth and industrialization in the world today, there is an increase in anthropogenic activities which have resulted in soil pollution due to waste being dumped on soils [13]. In trying to sustain this increasing population, man turns to the soil for crop production, thus making the soil an indispensable tool for man's survival. The fear of agricultural soils being contaminated by wastes dumped on them is a major concern.

The city of Bamenda, North-West Cameroon, has witnessed a rapid increase in population over the years, and this has resulted in large quantities of wastes being dumped on and around farmlands. The population growth, metal workshops, and use of metal appliances have experienced an increase in this city, which has resulted in the dumping of large quantities of metallic wastes on agricultural farmlands. Confronted with the above problem, the objective of this research was to assess some physicochemical properties and trace element content of soil and Zea mays (maize) samples from farmed dumpsites in the Bamenda metropolis and their environmental implications.

\section{Materials and Methods}

2.1. Site Descriptions and Sample Collection. The study area is located in the grass field zone of Cameroon, precisely in the Mezam Division of the North-West Region of Cameroon. Mezam is located on latitude $05^{\circ} 58^{\prime} 42.6^{\prime \prime} \mathrm{N}$ and longitude $10^{0} 8^{\prime} 52^{\prime \prime} \mathrm{E}$ and has an elevation of $1229 \mathrm{~m}$ above sea level. The land surface area is about $1745 \mathrm{~km}^{2}$, and its population density as of the year 2005 stood at 300.35 habitants $/ \mathrm{km}^{2}$ (Bamenda City Council Development Plan, 2015). The Mezam Division is made up of seven subdivisions, and three of these subdivisions (Bamenda I, Bamenda II, and Bamenda III) were selected for this study (Figure 1).

Fieldwork was carried out in December 2018. Three representative sites were chosen for sampling, based on the consideration that the land was being cultivated and was previously or is still being used as a garbage dumping site. The sites are Nkwen (S1), Mankon (S2), and Bamendakwe (S3). For each sampling site, soil and maize samples were collected. The soil samples were collected to a depth of $30 \mathrm{~cm}$.

The first study site is located in Nkwen, Bamenda III subdivision. It lays directly behind the Mile four Nkwen market, about $100 \mathrm{~m}$ away from mile four junction. The study site is located on latitude $05^{\circ} 59^{\prime} 03.59^{\prime \prime} \mathrm{N}$ and longitude $10^{\circ} 11^{\prime} 03.5^{\prime \prime} \mathrm{E}$, with an altitude of $1228 \mathrm{~m}$ above sea level. The vegetation is grassland type and the land is used for mixed cropping (maize-Zea mays, beans-Phaseolus vulgaris, and cocoyams-Colocasia esculenta).

The second study site is found in Mankon, located in the Bamenda II subdivision. It is located about $70 \mathrm{~m}$ from mile six junction and about $10 \mathrm{~m}$ from the river Mezam. The study site is located on latitude $05^{\circ} 59^{\prime} 04.6^{\prime \prime} \mathrm{N}$ and longitude $10^{\circ} 07^{\prime} 43.1^{\prime \prime} \mathrm{E}$, with an altitude of $1222 \mathrm{~m}$ above sea level. The vegetation type is mixed with different crops being cultivated on the soil.

The third study site is found in Bamendakwe and is located in the Bamenda I subdivision. It is located at about $20 \mathrm{~m}$ away from the Dschang motor park, behind the Mazi voyage. The study site is located on latitude $05^{\circ} 56^{\prime} 35.9^{\prime \prime} \mathrm{N}$ and longitude $10^{\circ} 10^{\prime} 15.5^{\prime \prime} \mathrm{E}$, with an altitude of $1520 \mathrm{~m}$ above sea level. The vegetation is grassland type, and maize is cultivated on the soil.

2.2. Laboratory Analyses. The collected soil samples were air-dried in the laboratory, ground in a ceramic mortar using a pestle, and sieved through a $2 \mathrm{~mm}$ sieve. Maize samples were washed using running tap water to eliminate dust, pesticides, fertilizers, mud, and any airborne pollutants that may be present. The maize samples were dried at room temperature. After that, the samples were sliced using a stainless steel knife, weighed, and oven-dried at $80^{\circ} \mathrm{C}$ for 72 hours. The oven-dried maize samples were then powdered and sieved through a $2 \mathrm{~mm}$ sieve. The less than $2 \mathrm{~mm}$ soil and plant samples were then analyzed for various physicochemical properties and heavy metals using international standard methods $[14,15]$.

Soil $\mathrm{pH}$ was measured in a $1: 2.5$ soil solution ratio in distilled water $\left(\mathrm{pH}-\mathrm{H}_{2} \mathrm{O}\right)$ and $1 \mathrm{~N} \mathrm{KCl}(\mathrm{pH}-\mathrm{KCl})$. Exchangeable bases were determined by the method of Schollenberger by percolating $2.5 \mathrm{~g}$ of soil sample with $100 \mathrm{~mL}$ of $1 \mathrm{~N}$ ammonium acetate, after which sodium and potassium ions were determined by flame photometry, while calcium and magnesium ions were estimated by complexometric titration. Cation exchange capacity (CEC) was estimated by percolating $2.5 \mathrm{~g}$ of soil sample with $100 \mathrm{~mL}$ of $1 \mathrm{~N}$ ammonium acetate and then with $1 \mathrm{~N} \mathrm{KCl}$, and the collected $\mathrm{NH}_{4}{ }^{+}$ions were then determined by distillation and titration with a $0.01 \mathrm{~N}$ sulphuric acid. Total nitrogen was estimated by exploiting Kjeldahl's distillation method, while soil organic carbon (SOC) was estimated by oxidation with potassium dichromate and titration with iron (II) sulphate. Particle size distribution was determined by the hydrometer method. The available phosphorus was determined by the Bray II method. The levels of trace elements were determined by atomic absorption spectrometric (AAS) analysis.

\section{Results and Discussion}

The soil physicochemical properties are presented in Table 1, while plant physicochemical properties are presented in Table 2.

The results of soil analysis showed that soil $\mathrm{pH}$ ranged from 5.63 for soils of Bamendakwe to 7.49 for soils of 


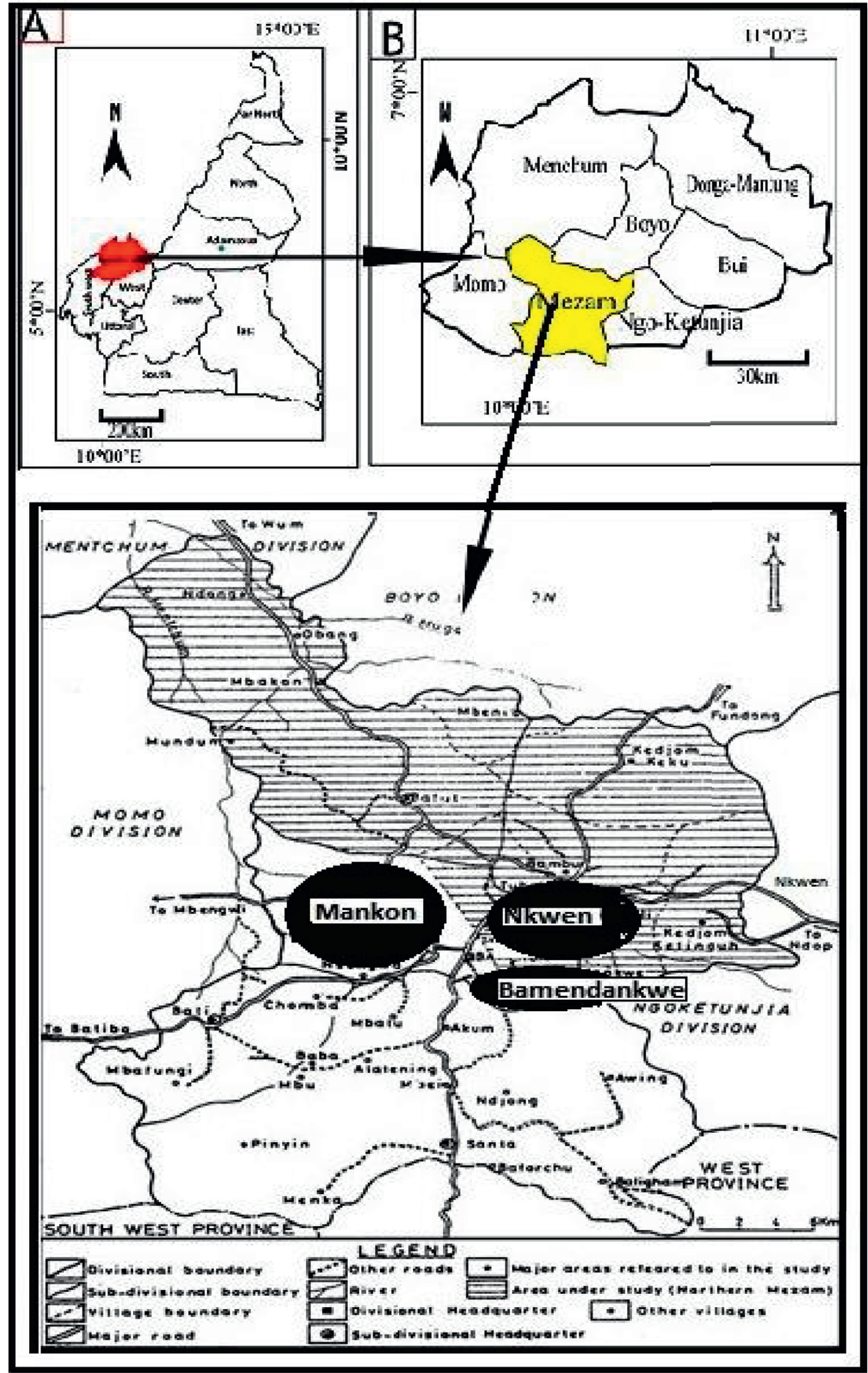

Figure 1: Map of the northwest region showing the study area and the different sampling sites (Bamenda City Council Development Plan, 2015).

Mankon (Table 1). The soils of Nkwen and Bamendakwe were moderately acidic, while those of Mankon were slightly alkaline [16]. The soils of Nkwen and Bamendakwe were moderately acidic and high in organic matter. The decomposition of this high organic matter can likely release carbon dioxide that reacts with water to produce carbonic 
TABLE 1: Soil physicochemical properties.

\begin{tabular}{lccc}
\hline & Nkwen (S1) & Mankon (S2) & Bamendakwe (S3) \\
\hline $\mathrm{pH}-\mathrm{H}_{2} \mathrm{O}$ & 5.68 & 7.49 & 5.63 \\
$\mathrm{pH}-\mathrm{KCl}$ & 4.8 & 7.45 & 4.45 \\
$\Delta \mathrm{pH}$ & -0.88 & -0.04 & -1.18 \\
$\% \mathrm{~N}$ & 0.13 & 0.20 & 0.15 \\
$\% \mathrm{OC}$ & 2.22 & 4.44 & 3.89 \\
$\% \mathrm{OM}$ & 3.83 & 7.66 & 6.70 \\
$\mathrm{C} / \mathrm{N}$ & 18 & 23 & 26 \\
$\mathrm{CEC}(\mathrm{cmol}(+) / \mathrm{kg})$ & 50.88 & 48.32 & 42.72 \\
$\mathrm{AP}(\mathrm{mg} \mathrm{kg})$ & 13.59 & 52.58 & 4.51 \\
$\mathrm{~K}(\mathrm{cmol}(+) / \mathrm{kg})$ & 0.64 & 0.64 & 0.64 \\
$\mathrm{Na}(\mathrm{cmol}(+) / \mathrm{kg})$ & 0.28 & 0.28 & 0.28 \\
$\mathrm{Ca}(\mathrm{cmol}(+) / \mathrm{kg})$ & 5.60 & 5.38 & 4.64 \\
$\mathrm{Mg}(\mathrm{cmol}(+) / \mathrm{kg})$ & 4.00 & 2.64 & 3.04 \\
$\mathrm{SB}(\mathrm{cmol}(+) / \mathrm{kg})$ & 10.52 & 8.92 & 8.60 \\
$\mathrm{TBS}(\%)$ & 20.68 & 18.46 & 20.13 \\
Sand $(\%)$ & 40 & 62 & 63 \\
Silt $(\%)$ & 30 & 24 & 18 \\
$\mathrm{Clay}(\%)$ & 30 & 14 & 19 \\
\hline
\end{tabular}

$\Delta \mathrm{pH}=$ net charge $\left(\mathrm{pH}-\mathrm{KCl}-\mathrm{pH}-\mathrm{H}_{2} \mathrm{O}\right), \mathrm{OC}=$ organic carbon, $\mathrm{N}=$ total nitrogen, $\mathrm{OM}=$ organic matter, $\mathrm{C} / \mathrm{N}=$ mineralization factor, $\mathrm{CEC}=$ cation exchange capacity, $\mathrm{AP}=$ available phosphorus, $\mathrm{SB}=$ sum of bases, $\mathrm{TBS}=$ total base saturation, $\mathrm{CL}=$ clay loam, and $\mathrm{SL}=$ sandy loam.

TABLE 2: Maize plant physicochemical properties.

\begin{tabular}{lccc}
\hline & Nkwen (S1) & Mankon (S2) & Bamendakwe (S3) \\
\hline$\%$ ash content & 9 & 11 & 7 \\
$\%$ WC & 9 & 5 & 5 \\
$\% \mathrm{~N}$ & 4.20 & 5.60 & 12.60 \\
$\%$ OC & 22.14 & 22.45 & 23.26 \\
$\%$ OM & 38.17 & 38.70 & 40.09 \\
$\mathrm{C} / \mathrm{N}$ & 5.27 & 4.01 & 1.85 \\
$\mathrm{TP}\left(\mathrm{mg} \mathrm{kg}{ }^{-1}\right)$ & 136.90 & 1830.15 & 1312.15 \\
$\mathrm{~K}(\mathrm{cmol}(+) / \mathrm{kg})$ & 35.80 & 12.90 & 21.70 \\
$\% \mathrm{DWK}$ & 1.40 & 0.50 & 0.85 \\
$\mathrm{Na}(\mathrm{cmol}(+) / \mathrm{kg})$ & 1.95 & 1.03 & 1.26 \\
$\% \mathrm{DWNa}$ & 0.04 & 0.02 & 0.03 \\
$\mathrm{Ca}(\mathrm{cmol}(+) / \mathrm{kg})$ & 54.80 & 66.80 & 30.80 \\
$\% \mathrm{DWCa}$ & 1.10 & 1.34 & 0.62 \\
$\mathrm{Mg}(\mathrm{cmol}(+) / \mathrm{kg})$ & 11.20 & 11.20 & 7.20 \\
$\% \mathrm{DWMg}$ & 0.14 & 0.14 & 0.09 \\
\hline
\end{tabular}

$\mathrm{WC}=$ water content, $\mathrm{N}=$ total nitrogen, $\mathrm{OC}=$ organic carbon, $\mathrm{OM}=$ organic matter, $\mathrm{C} / \mathrm{N}=$ mineralization factor, $\mathrm{TP}=$ total phosphorus, $\mathrm{DWK}=\mathrm{dry}$ weight of potassium, DWNa = dry weight of sodium, DWCa $=$ dry weight of calcium, and DWMg = dry weight of magnesium.

acid. The acid formed reduces soil $\mathrm{pH}$ and this adversely affects microorganisms and increases the solubility and mobility of heavy metals in soil [17]. The soil $\mathrm{pH}$ can be raised to acceptable levels by liming the soils. Since the $\mathrm{pH}$ of the soil sample of Mankon fell within the neutral zone (6-8), the soil may be favourable for plant growth [18]. The sign and magnitude of $\Delta \mathrm{pH}$, which corresponds to the sign and magnitude of soil surface charge, were negative for all the soils with values ranging from -1.18 to -0.04 , indicating that these soils were above their point of zero charge. This shows that they had net negatively charged surfaces, resulting in a net CEC at field $\mathrm{pH}$ [19]. These soil $\mathrm{pH}$ values conform to those reported by Anikwe and Nwobodo [20] while investigating long-term effects of municipal waste disposal on soil properties and productivity of sites used for urban agriculture in Abakali, Nigeria.
Organic matter ranged from $3.83 \%$ for soils of Nkwen to $7.66 \%$ for soils of Mankon (Table 1). It was observed that the OM content of Nkwen was medium, while that of Mankon and Bamendakwe was high. The high OM matter content for the soils of Mankon and Bamendakwe was due to organic waste dumped directly on the surface of this farmed site which increases the organic matter content of the soil, while the medium value obtained for the soil of Nkwen could be due to the fact that organic waste was dumped around this farmed site and not directly on the surface of the farm site as observed in the field. The organic matter content of all the three soils was of poor quality. This poor quality could be due to their high mineralization factor $(\mathrm{C} / \mathrm{N}$ ratio) which slowed down the decomposition rate of organic material with lower mobilization of nitrogen [21]. To lower the mineralization factor, nitrogen-containing fertilizers could be applied on 
such soils to help increase the decomposition of organic material and improve its quality. Soil organic matter positively influences the concentrations of other soil properties such as total nitrogen and available phosphorus $[16,17,20]$. Soil organic matter values are similar to those reported by Nimyel et al. [22] who studied heavy metal concentrations in some vegetables grown in farms treated with urban solid waste in Kuru, Jantai, Nigeria.

The total nitrogen content was low in all the three soils. Its values ranged from 0.13 to $0.2 \%$ (Table 1 ). The $\mathrm{C} / \mathrm{N}$ ratio for the soils was high with values ranging from 18 to 26 . High $\mathrm{C} / \mathrm{N}$ ratios indicated that the organic matter content was poorly mineralized [23]. High soil $\mathrm{C} / \mathrm{N}$ ratio could slow down the decomposition rate of organic matter. Wider $\mathrm{C} / \mathrm{N}$ ratios, as shown by the results, indicate a shortage of nitrogen for microbial protein synthesis resulting in competition for the available nitrogen, and hence, it will become immobilized, thus unavailable to plants. The soil total nitrogen content ( 0.13 to $0.2 \%$ ) in this study was different from the high values reported by Anikwe and Nwobodo [20] on the long-term effects of municipal waste disposal on soil properties and productivity of sites used for urban agriculture in Abakali, Nigeria.

Cation exchange capacity was high for all three soils with values ranging from 40.88 to $48.32 \mathrm{cmol}(+) / \mathrm{kg}$ (Table 1). The soils of Mankon and Bamendakwe had comparatively lower CEC values (48.32 and $42.72 \mathrm{cmol}(+) / \mathrm{kg}$, respectively), indicating that these soils were made of sand with a low water and nutrient holding capacity, which implies soils of this nature are very susceptible to cation nutrient loss through leaching [24]. The soils of Nkwen had a comparatively higher CEC value $(50.88 \mathrm{cmol}(+) / \mathrm{kg})$ compared to that observed for Mankon and Bamendakwe, which indicates that the soils had more clay, high water, and nutrient holding capacity, which implies soils of this nature are not very susceptible to cation nutrient loss since the cation is tightly held by the clay [24]. The values of CEC obtained in this study are in conformity with those reported by Nimyel et al. [22].

The sum of the exchangeable bases ranged from 8.60 to $10.52 \mathrm{cmol}(+) / \mathrm{kg}$ (Table 1). The high values of exchangeable bases could have resulted from the input of solid waste dumped on these sites, which, upon microbial breakdown of organic waste, releases these macronutrients into the soil for plant absorption [17]. Base saturation, which is the percentage of the soil CEC that is occupied by basic cations (calcium, magnesium, potassium, and sodium) at the current soil $\mathrm{pH}$ value, was less than $50 \%$ for all three soils, a fact which shows that the majority of the soils studied are acidic in nature.

The available phosphorus for all three soil samples ranged from 4.51 to $52.58 \mathrm{mg} \mathrm{kg}^{-1}$ (Table 1). Soils of Mankon had the highest available phosphorus $\left(52.58 \mathrm{mg} \mathrm{kg}^{-1}\right)$, which could be due to its high organic matter content resulting from waste dump on this site and almost neutral $\mathrm{pH}$ which positively influences the concentration of available phosphorus present [25]. The soils of Nkwen and Bamendakwe had low values of available phosphorus. This could be due to their slightly acidic nature which permits phosphorus fixation.
Soil texture (Table 1) showed that soils of Nkwen were clay loam, fine-textured soil with a high water and nutrient holding capacity, while those of Mankon and Bamendakwe were of soil type sandy loam, coarse-textured soils with a low water and nutrient holding capacity [26, 27].

Ash content is a measure of the total amount of minerals present within a food or plant [28]. Ash content analysis for all three maize plant samples ranged from 7 to $11 \%$ (Table 2), with samples of Mankon having the highest ash content which could be due to its slightly alkaline $\mathrm{pH}$ that favoured mineral uptake. The plant samples of Nkwen and Bamendakwe had low ash content. The $\mathrm{pH}$ of acidic soils can be raised to a value around neutrality to increase the mineral content in plants since they are readily available at soil $\mathrm{pH}$ around neutrality [18].

The WC in all three plants ranged from 5\% to $9 \%$ (Table 2). The plant samples of Nkwen had the highest water content (9\%) which could be due to the nature of its soil which is clay loam with a high water holding capacity. The plant samples of Mankon and Bamendakwe had a water content of $5 \%$, which could be due to the sandy nature of the soils with a low water holding capacity.

The organic matter content for all three plant samples was found to be very high, with values ranging from $38.17 \%$ to $40.09 \%$ (Table 2). This high value of OM in plants could mean that though the soil organic matter was poorly mineralized, plants were able to take up the maximum amount of mineralized organic matter from the soil.

The total nitrogen content in all three plant samples ranges from $4.20 \%$ to $12.60 \%$, which is by far greater than the values obtained for the soil nitrogen content at a depth of $30 \mathrm{~cm}$. In addition to obtaining nitrogen from soil, plants can also obtain nitrogen from the atmosphere by nitrogen fixation. This high value for nitrogen obtained in plants might also be due to the fact that plant roots were capable of absorbing available nitrogen found within the depth of $30 \mathrm{~cm}$ and beneath [29].

The total phosphorus in all three sampled plants was very high, ranging from 1312.15 to $1830.15 \mathrm{mg} \mathrm{kg}^{-1}$. These high values could be due to very high organic matter in the plant which also influences parameters like the available phosphorus [17].

The exchangeable bases in the plant were higher compared to the amounts present in the soil. This result showed that basic cations were high in these dumpsites, which permitted the proper functioning of some enzymes in plants to be able to absorb these ions from the soil solution [11].

The results of total heavy metal concentration in soil and plant samples are presented in Tables 3 and 4, respectively. Each trace element is considered in a sequence for discussion:

Zinc ( $\mathrm{Zn}$ ): the total concentrations of zinc in the soil samples were $34.61,1438.36$, and $137.54 \mu \mathrm{g} / \mathrm{g}$ for Nkwen, Mankon, and Bamendakwe, respectively. The soil samples of Mankon had its concentration above the maximum permissible limit $(300 \mu \mathrm{g} / \mathrm{g})$ (Table 3), implying that the soils of Mankon are suffering from zinc pollution. The total concentrations of zinc in the plant samples were $50.19,114.48$, and $94.76 \mu \mathrm{g} / \mathrm{g}$ for Nkwen, 
TABLe 3: Trace element content in soil.

\begin{tabular}{lcccc}
\hline Site (sample) & $\mathrm{Zn}(\mu \mathrm{g} / \mathrm{g})$ & $\mathrm{Cu}(\mu \mathrm{g} / \mathrm{g})$ & $\mathrm{Mn}(\mu \mathrm{g} / \mathrm{g})$ & $\mathrm{Fe}(\mu \mathrm{g} / \mathrm{g})$ \\
\hline Nkwen (S1) & 34.61 & 18.95 & 122 & 33484.6 \\
Mankon (S2) & 1438.36 & 157.17 & 1273 & 35237.7 \\
Bamendakwe (S3) & 137.54 & 20.04 & 1126 & 146353.6 \\
MAC & 300 & 100 & 1500 & 50000 \\
\hline
\end{tabular}

$\mathrm{MAC}=$ maximum allowable concentration $[7,30]$.

TABLe 4: Trace element content in plant.

\begin{tabular}{lcccc}
\hline Site (sample) & $\mathrm{Zn}(\mu \mathrm{g} / \mathrm{g})$ & $\mathrm{Cu}(\mu \mathrm{g} / \mathrm{g})$ & $\mathrm{Mn}(\mu \mathrm{g} / \mathrm{g})$ & $\mathrm{Fe}(\mu \mathrm{g} / \mathrm{g})$ \\
\hline Nkwen (S1) & 50.19 & 2.92 & 58.86 & 3694.29 \\
Mankon (S2) & 114.40 & 3.42 & 42.48 & 4308.39 \\
Bamendakwe (S3) & 94.76 & 3.40 & 38.44 & 1817.87 \\
MAC & 100 & 73 & 500 & 425 \\
\hline
\end{tabular}

$\mathrm{MAC}=$ maximum allowable concentration $[7,30]$.

Mankon, and Bamendakwe, respectively. The total concentration of $\mathrm{Zn}$ in the plant sample of Mankon was above the maximum permissible limit $(100 \mu \mathrm{g} / \mathrm{g})(\mathrm{Ta}-$ ble 4). This shows that maize grown on this soils absorbs a good portion of the zinc found in the soil. These high levels of $\mathrm{Zn}$ in soils may inhibit many plant metabolic functions, resulting to retarded growth [31]. Zinc is an essential trace element for plants, animals, and humans found in virtually all food [32]. Zinc is used to form connective tissues like ligaments and tendons [33]. Zinc toxicity in humans is rare, but at higher concentrations, it may induce toxicity characterized by symptoms of irritability, muscular stiffness, and pain [34]. Thus, consumers of maize grown on the soils of Mankon are likely to suffer from diseases associated with $\mathrm{Zn}$ toxicity.

Copper $(\mathrm{Cu})$ : the total concentrations of copper in the soil samples were $18.95,157.17$, and $20.04 \mu \mathrm{g} / \mathrm{g}$ for Nkwen, Mankon, and Bamendakwe, respectively. The soil samples of Mankon had its concentration of $\mathrm{Cu}$ above the maximum permissible limit $(100 \mu \mathrm{g} / \mathrm{g})$ (Table 3). The total concentrations of copper in the plant samples were $2.92,3.42$, and $3.40 \mu \mathrm{g} / \mathrm{g}$ for Nkwen, Mankon, and Bamendakwe, respectively. The total concentrations of $\mathrm{Cu}$ in all plant samples were below the maximum permissible limit $(73 \mu \mathrm{g} / \mathrm{g}$ ) (Table 4 ) and present no risk of contamination at the moment. The soils of Mankon have to be continuously monitored because other crops grown on this soil may absorb $\mathrm{Cu}$ above permissible limits or leaching may occur into nearby water bodies that the population of the area depends on.

Manganese (Mn): the total concentrations of manganese in the soil samples were 122, 1273, and $1126 \mu \mathrm{g} / \mathrm{g}$ for Nkwen, Mankon, and Bamendakwe, respectively. The total concentrations of $\mathrm{Mn}$ in all soil samples were below the maximum permissible limit set $(1500 \mu \mathrm{g} / \mathrm{g})$ (Table 3). The total concentrations of manganese in the plant samples were 58.86, 42.48, and $38.44 \mu \mathrm{g} / \mathrm{g}$ for Nkwen, Mankon, and
Bamendakwe, respectively. The total concentrations of $\mathrm{Mn}$ in all plant samples were equally below the maximum permissible limit $(500 \mu \mathrm{g} / \mathrm{g})$ (Table 4). Manganese is essential for the normal physiological functioning of humans and animals, and exposure to low levels of manganese in the diet is considered nutritionally essential in humans. However, chronic exposure to higher doses is detrimental to human health [35].

Iron $(\mathrm{Fe})$ : the total concentrations of iron in the soil samples were 33484.6, 35237.7, and $146353.6 \mu \mathrm{g} / \mathrm{g}$ for Nkwen, Mankon, and Bamendakwe, respectively. Soil samples of Nkwen and Mankon had their concentration of iron below the maximum permissible limits $(50000 \mu \mathrm{g} / \mathrm{g})$ (Table 3), while soils of Bamendakwe had concentration of iron above the maximum permissible limits. The total concentrations of iron in the plant samples were $3694.29,4308.39$, and $1817.87 \mu \mathrm{g} / \mathrm{g}$ for Nkwen, Mankon, and Bamendakwe. Very high total concentrations of total could be from the soil parent materials (basalt, trachytes, and rhyolite) which are natural sources of $\mathrm{Fe}$ in the soil, and it could also be emanating from organic wastes dumping $[12,36]$. The total concentrations of $\mathrm{Fe}$ in all plant samples were above the maximum permissible limit $(425 \mu \mathrm{g} / \mathrm{g}$ ) (Table 4). Excess amount of iron causes a rapid increase in pulse rate and coagulation of blood in blood vessels, hypertension, and drowsiness [37]. Thus, consumers of maize grown on the soils of the three study sites are likely to suffer from diseases associated with Fe toxicity.

Soil pollution by trace elements negatively affects plant growth and degrades soil quality and the quality of agricultural products $[31,38]$. The mobilization of nutrient ions and immobilization of heavy metals by induced liming could be important in sustainable agricultural production and soil environmental protection of the soils studied.

Significant correlations $(p<0.05)$ were recorded between most soil physicochemical properties (Table 5). Soil organic matter was shown to correlate positively with the soil nitrogen $(r=0.866)$, suggesting that an increase in the soil's organic matter also increases soil nitrogen since nitrogen is a macroplant nutrient, and this nutrient availability in a soil is said to increase with an increase in soil organic matter [17]. The above results show that there exists a relationship between the soil physicochemical properties which affects the availability of nutrients [39].

Significant correlations $(p<0.05)$ were also observed between soil and plant physicochemical properties (Table 6).

The soil organic matter was shown to correlate positively with plant-available phosphorus $(r=0.998)$ and potassium $(r=0.989)$. Soil organic matter upon mineralization positively influences parameters like phosphorus and nitrogen availability. This is true because nitrogen, potassium, and phosphorus are the main plant macronutrients and are controlled by the amount of soil organic matter; therefore, the higher the soil organic matter, the fertile the soil; hence, the more available are the plant nutrients. The soil-plant correlation results 
TABLE 5: Correlation between soil physicochemical properties.

\begin{tabular}{|c|c|c|c|c|c|c|c|c|c|c|}
\hline & $\mathrm{N}$ & $\mathrm{pH}-\mathrm{H}_{2} \mathrm{O}$ & $\mathrm{pH}-\mathrm{KCl}$ & $\mathrm{OM}$ & CEC & SB & AP & Sand & Silt & Clay \\
\hline $\mathrm{N}$ & 1 & - & - & - & - & - & - & - & - & - \\
\hline $\mathrm{pH}-\mathrm{H}_{2} \mathrm{O}$ & 0.954 & 1 & - & - & - & - & - & - & - & - \\
\hline $\mathrm{pH}-\mathrm{KCl}$ & 0.926 & 0.997 & 1 & - & - & - & - & - & - & - \\
\hline $\mathrm{OM}$ & $0.866^{*}$ & 0.677 & 0.613 & 1 & - & - & - & - & - & - \\
\hline CEC & -0.069 & 0.233 & 0.313 & -0.558 & 1 & - & - & - & - & - \\
\hline SB & -0.604 & -0.337 & -0.258 & -0.921 & 0.837 & 1 & - & - & - & - \\
\hline $\mathrm{AP}$ & 0.897 & 0.988 & $0.998^{*}$ & 0.556 & 0.379 & -0.189 & 1 & - & - & - \\
\hline Sand & 0.693 & 0.445 & 0.369 & 0.961 & -0.767 & -0.993 & 0.303 & 1 & - & - \\
\hline Silt & -0.277 & 0.024 & 0.107 & -0.720 & 0.978 & 0.933 & 0.176 & -0.885 & 1 & - \\
\hline Clay & -0.898 & -0.725 & -0.665 & $-0.998^{*}$ & 0.501 & 0.893 & -0.611 & -0.940 & 0.672 & 1 \\
\hline
\end{tabular}

*Correlation is significant at the 0.05 level (2-tailed).

TABle 6: Correlation between soil and plant physicochemical properties.

\begin{tabular}{|c|c|c|c|c|c|c|c|c|c|c|c|c|}
\hline & $\mathrm{N}_{\mathrm{s}}$ & $\mathrm{N}_{\mathrm{p}}$ & $\mathrm{OM}_{\mathrm{s}}$ & $\mathrm{OM}_{\mathrm{p}}$ & $\mathrm{AP}_{\mathrm{s}}$ & $\mathrm{AP}_{\mathrm{p}}$ & $\mathrm{K}_{\mathrm{p}}$ & $\mathrm{Na}_{\mathrm{p}}$ & $\mathrm{Ca}_{\mathrm{s}}$ & $\mathrm{Ca}_{\mathrm{p}}$ & $\mathrm{Mg}_{\mathrm{s}}$ & $\mathrm{Mg}_{\mathrm{p}}$ \\
\hline $\mathrm{N}_{\mathrm{s}}$ & 1 & - & - & - & - & - & - & - & - & - & - & - \\
\hline $\mathrm{N}_{\mathrm{p}}$ & -0.086 & 1 & - & - & - & - & - & - & - & - & - & - \\
\hline $\mathrm{OM}_{\mathrm{s}}$ & $0.866^{*}$ & 0.423 & 1 & - & - & - & - & - & - & - & - & - \\
\hline $\mathrm{OM}_{\mathrm{p}}$ & 0.030 & $0.993^{* *}$ & 0.525 & 1 & - & - & - & - & - & - & - & - \\
\hline $\mathrm{AP}_{\mathrm{s}}^{\mathrm{P}}$ & $0.897^{*}$ & -0.518 & 0.556 & -0.415 & 1 & - & - & - & - & - & - & - \\
\hline $\mathrm{AP}_{\mathrm{p}}$ & $0.895^{*}$ & 0.368 & $0.998^{* *}$ & 0.473 & 0.605 & 1 & - & - & - & - & - & - \\
\hline $\mathrm{K}_{\mathrm{p}}$ & $-0.930^{* *}$ & -0.285 & $-0.989^{* *}$ & -0.394 & -0.672 & $-0.996^{* *}$ & 1 & - & - & - & - & - \\
\hline $\mathrm{Na}_{\mathrm{p}}$ & $-0.866^{*}$ & -0.423 & $-1.000^{* *}$ & -0.526 & -0.556 & $-0.998^{*}$ & $0.989^{*}$ & 1 & - & - & - & - \\
\hline $\mathrm{Ca}_{\mathrm{s}}$ & 0.000 & $-0.996^{* *}$ & -0.499 & $-1.000^{*}$ & 0.442 & -0.447 & 0.367 & 0.500 & 1 & - & - & - \\
\hline $\mathrm{Ca}_{\mathrm{p}}$ & 0.545 & $-0.882^{*}$ & 0.53 & $-0.822^{*}$ & $0.859^{*}$ & 0.113 & -0.199 & -0.052 & $0.839^{*}$ & 1 & - & - \\
\hline $\mathrm{Mg}_{\mathrm{s}}$ & $-0.889^{*}$ & -0.380 & $-0.999^{* *}$ & -0.485 & -0.595 & $-1.000^{* *}$ & $0.995^{* *}$ & $0.999^{* *}$ & 0.458 & -0.100 & 1 & - \\
\hline $\mathrm{Mg}_{\mathrm{p}}$ & 0.240 & $-0.988^{* *}$ & -0.277 & $-0.963^{* *}$ & 0.645 & -0.219 & 0.132 & 0.277 & $0.971^{* *}$ & $0.945^{* *}$ & 0.231 & 1 \\
\hline
\end{tabular}

Subscripts s and p stand for soil and plant, respectively. ${ }^{* *}$ Correlation is significant at the 0.01 level (2-tailed). ${ }^{*}$ Correlation is significant at the 0.05 level (2-tailed).

showed that plants depend on the soil physicochemical properties for plant nutrients availability. The correlation results revealed that relationships existing between soil physicochemical properties interfered with nutrient availability. The positive correlation between soil organic matter and plant-available phosphorus agrees with the findings of Tsozue et al. [21] who reported that plant nutrient availability depends on the relationship existing between soil and physicochemical properties. The trace elements analyzed showed a significant correlation with one another $(p<0.05) . \mathrm{Zn}$ and $\mathrm{Cu}$ showed a positive correlation $(r=0.998, p=0.038)$, suggesting they could have a common origin [40].

\section{Conclusion}

The main aim of this study was to assess the physicochemical and trace element ( $\mathrm{Zn}, \mathrm{Mn}, \mathrm{Cu}$, and $\mathrm{Fe}$ ) properties of some farmed dump soils and maize plants in the Bamenda metropolis. The results showed that the soils had $\mathrm{pH}$ values ranging from 5.63 to 7.49 , average organic matter, medium total nitrogen, high $\mathrm{C} / \mathrm{N}$ ratios, and high CEC values, and particle size analysis showed that the soil textural class was clay loam for soil samples of Nkwen and sandy loam for soil samples of Mankon and Bamendakwe, ash content was low in plants, and high values for OM, available phosphorus, and total nitrogen were observed in the plant samples. The results of trace elements showed that some soils and plant samples were contaminated to different levels by different trace elements. The results obtained in this study show that the concentrations of trace metals at dumpsites are higher, which calls for concern to the environment and humans who depend solely on the soil in the dumpsite zones for survival. Further research should aim to analyze nearby streams, those directly linked to farmed dumpsites, to evaluate potential risk of contamination of the water bodies.

\section{Data Availability}

Relevant data are available for consultation if needed.

\section{Conflicts of Interest}

The authors declare that there are no conflicts of interest regarding the publication of this paper.

\section{Acknowledgments}

The authors are grateful to the farmers of the different farmed dumpsites in the Bamenda metropolis for helping in identifying the farmed dumpsites and for permitting us to use their fields for this study. All technicians of the Research Unit of Soil Analysis and Environmental Chemistry 
(RUSAEC), University of Dschang, and the International Institute of Tropical Agriculture (IITA), Nkolbisson, Yaounde, are acknowledged for assisting in laboratory analyses.

\section{References}

[1] A. Khan and A. Ghouri, "Environmental pollution and its effects on life and its remedies," Journal of Arts, Science and Commerce, vol. 2, no. 2, pp. 276-285, 2011.

[2] R. Yunginger, S. Bijaksana, D. Dahrin et al., "Lithogenic and anthropogenic components in surface sediments from lake limboto as shown by magnetic mineral characteristics, trace metals, and REE geochemistry," Geosciences (Switzerland), vol. 8, no. 4, p. 116, 2018.

[3] I. V. Perminova, J.-M. García-Mina, H. Knicker, and T. Miano, "Humic substances and nature-like technologies," Journal of Soils and Sediments, vol. 19, no. 6, pp. 2663-2664, 2019.

[4] A. Begum, M. Ramaiah, K. I. Khan, and K. Veena, "Heavy metal pollution and chemical profile of cauvery River water," E-journal of Chemistry, vol. 6, no. 1, pp. 47-52, 2009.

[5] F. Lisetskii, E. Zelenskaya, and M. Rodionova, "Geochemical features of fallow land in ancient plots in the chora of chersonesos," Geosciences, vol. 8, no. 11, p. 410, 2018.

[6] G. M. Pierzynski, G. T. Sims, and G. F. Vance, Soils and Environmental Quality, CRC Press, London UK, 2nd edition, 2000.

[7] A. Kabata-Pendias, Trace Elements in Soils and Plants, CRC Press, Taylor and Francis Group, LLC, New York, NY, USA, 4th edition, 2011.

[8] S. Khan, Q. Cao, Y. M. Zheng, Y. Z. Huang, and Y. G. Zhu, "Health risks of heavy metals in contaminated soils and food crops irrigated with wastewater in Beijing, China," Environmental Pollution, vol. 152, no. 3, pp. 686-692, 2008.

[9] V. P. Kalinitchenko, A. P. Glinushkin, T. M. Minkina et al., "Chemical soil-biological engineering theoretical foundations, technical means, and technology for safe intrasoil waste recycling and long-term higher soil productivity," ACS Omega, vol. 5, no. 28, pp. 17553-17564, 2020.

[10] D. Bitondo, F. O. Tabi, S. S. A. Kengmegne, M. Ngoucheme, and A. D. MvondoZe, "Micronutrient concentrations and environmental concerns in an intensively cultivated typic dystrandept in mount bambouto, Cameroon," Open Journal of Soil Science, vol. 03, no. 06, pp. 283-288, 2013.

[11] M. N. V. Prasad, Trace Elements as Contaminants and Nutrients: Consequences in Ecosystems and Human Health, p. 1002, New York, NY, USA, 2008.

[12] N. A. Mofor, E. B. N. Tamungang, A. D. Mvondo-zé, G. K. Kome, and K. Mbene, "Assessment of physico-chemical and heavy metals properties of some agricultural soils of awing-north west Cameroon," Archives of Agriculture and Environmental Science, vol. 2, no. 4, pp. 277-286, 2017.

[13] P. Goel, Water Pollution: Causes, Effects and Control, New Age International Publishers, New Delhi, India, 2nd edition, 2009.

[14] J. M. Pauwels, E. Van Ranst, M. Verboo, and A. D. Mvondoze, Manuel de Laboratoire de Pedologie, Publications Agricoles, Bruxelles, Belgium, 1992.

[15] J. J. J. Benton, Agronomic Handbook- Management of Crops, Soils, and Their Fertility, CRC Press LLC., Boca Raton, FL, USA, 2003.

[16] D. A. Horneck, D. M. Sullivan, J. S. Owen, and J. M. Hart, Soil Test Interpretation Guide, Oregon State University Extension Service, Oregon State University, Corvallis, OR, USA, 2011.
[17] P. N. Okeke, "Impact of solid waste on physico chemical properties ferreal soil in Owerri, Nigeria," An International Multidisciplinary Journal, Ethopia, vol. 3, pp. 118-120, 2014.

[18] A. Lauchil and S. R. Grattan, Soil pH Extremes. Department of Land, Air and Water Resources, pp. 194-209, School of Plant Biology, University of Western Australia, Crawley, Australia, 2012.

[19] P. K. B. Yerima and E. Van Ranst, Introduction to Soils Science: oils of the Tropics, Flemish Interuniversity Council, Brussels, Belgium, 1st edition, 2005.

[20] M. Anikwe and K. C. A. Nwobodo, "Long term effect of municipal waste disposal on soil properties and productivity of sites used for urban agriculture in Abakaliki, Nigeria," Bioresource Technology, vol. 83, no. 3, pp. 241-250, 2002.

[21] D. Tsozué, P. Tematio, and P. A. Tamfuh, "Relationship between soil characteristics and fertility implications in two typical dystrandept soils of the Cameroon western highland," International Journal of Soil Science, vol. 11, no. 2, pp. 36-48, 2016.

[22] D. N. Nimyel, N. J. Egilia, and Y. N. Lohdip, "Heavy metal concentrations in some vegetables grown in a farm treated with urban solid waste in Kuru Jantai, Nigeria," British Journal of Applied Science and Technology, vol. 8, no. 2, pp. 139-147, 2015.

[23] P. Hazelton and B. Murphy, Interpreting Soil Test Results. What Do All the Numbers Mean?, CSIRO Publishing, Australia, 2nd edition, 2007.

[24] J. Spargo, T. Allen, and S. Kariuki, Interpreting Your Soil Test Results," The College of Natural Sciences Soil and Plant Tissue Testing Laboratory, United States Department of Agriculture (USDA), Washington, D.C., USA, 2013.

[25] E. B. T. Njoyim, A. D. Mvondo-Zé, J. N. Ghogomu, and N. A. Mofor, "Evaluation of phosphorus sorption characteristics of soils from the Bambouto sequence (West Cameroon)," International Journal of Biological and Chemical Science, vol. 10, no. 2, pp. 860-874, 2016.

[26] K. Kevin, N. Peter, and E. Quigley, Soil Types, Novascotia Department of Natural Resources, Bonjour, LA, USA, 2nd edition, 2010.

[27] T. N. Nath, "Soil texture and total organic matter content and its influences on soil water holding capacity of some selected tea growing soils in Sivasaga district of Assam, India," International Journal of Chemical Science, vol. 12, no. 4, pp. 1419-1429, 2014.

[28] P. J. Hofman, S. Vuthapanich, A. W. Whiley, A. Klieber, and D. H. simons, "Tree yield and fruit minerals concentrations influence "Hass" avocado fruit quality," Scientia Horticulturae, vol. 92, no. 2, pp. 113-123, 2002.

[29] P. Wang, J. Limpens, A. Nauta et al., "Depth-based differentiation in nitrogen uptake between graminoids and shrubs in an Arctic tundra plant community," Journal of Vegetation Science, vol. 29, no. 1, pp. 34-41, 2017.

[30] A. Manikandan, Heavy metal Pollution in Soil, Indian Council of Agricultural Research, Division of Agril. Chemistry and Soil Science, College of Agriculture, Pune-05, India, 2005.

[31] S. K. Yadav, "Heavy metals toxicity in plants: an overview on the role of glutathione and phytochelatins in heavy metal stress tolerance of plants," South African Journal of Botany, vol. 76, no. 2, pp. 167-179, 2010.

[32] S. Swaminathan, M. Seshadri, and Karagasapathy, "Effect of tannery effluent on the zinc content of ground water," Journal of Pharmaceutical and Biomedical Services, vol. 11, pp. 1-3, 2011.

[33] F. Miculescu, M. Miculescu, L. Ciocan et al., "Comparative studies regarding heavy elements concentration in human 
cortical bone," Digest Journal of Nanomaterials and Biostructures, vol. 6, pp. 1117-1127, 2011.

[34] M. Al-Weher, "Levels of heavy metal Cd, Cu and $\mathrm{Zn}$ in three fish species collected from the Northern Jordan Valley," Jordan Journal of Biological Sciences, vol. 1, pp. 41-46, 2008.

[35] M. Calkins, Materials for Sustainable Sites: A Complete Guide to the Evaluation, John Wiley \& Sons, Inc., Hoboken, NJ, USA, 2009.

[36] M. Economou-Eliopoulos, I. Megremi, C. Atsarou, C. Theodoratou, and C. Vasilatos, "Spatial evolution of the chromium contamination in soils from the assopos to thiva basin and C. Evia (Greece) and potential source(s): anthropogenic versus natural processes," Geosciences, vol. 3, no. 2, pp. 140-158, 2013.

[37] N. Ruqia, K. Muslim, M. Muhammad et al., "Accumulation of heavy metals ( $\mathrm{Ni}, \mathrm{Cu}, \mathrm{Cd}, \mathrm{Cr}, \mathrm{Pb}, \mathrm{Zn}, \mathrm{Fe}$ ) in the soil, water and plants and analysis of physico-chemical parameters of soil and water collected from Tanda Dam Kohat," Journal of Pharmaceutical Science \& Research, vol. 7, no. 3, pp. 89-97, 2015.

[38] P. C. Nagajyoti, K. D. Lee, and T. V. M. Sreekanth, "Heavy metals, occurrence and toxicity for plants: a review," Environmental Chemistry Letters, vol. 8, no. 3, pp. 199-216, 2010.

[39] Y. Jiang, G. Zang, D. Zou, Y. Quin, and W. J. Liang, "Profile distribution of micronutrients in aquic brown soils affected by land use," Journal of Soil and Plant Environment, vol. 155, no. 11 , pp. $468-476,2009$.

[40] M. T. Osobamiro and G. O. Adewuyi, "Levels of heavy metals in the soil: effects of season, agronomic practice and soil geology," Journal of Agricultural Chemistry and Environment, vol. 04, no. 04, pp. 109-117, 2015. 